\title{
EFFECTS OF SOCIAL ECONOMY SELECTED SEGMENTS IN THE SLOVAK REPUBLIC
}

\author{
Marcela Chreneková ${ }^{1}$
}

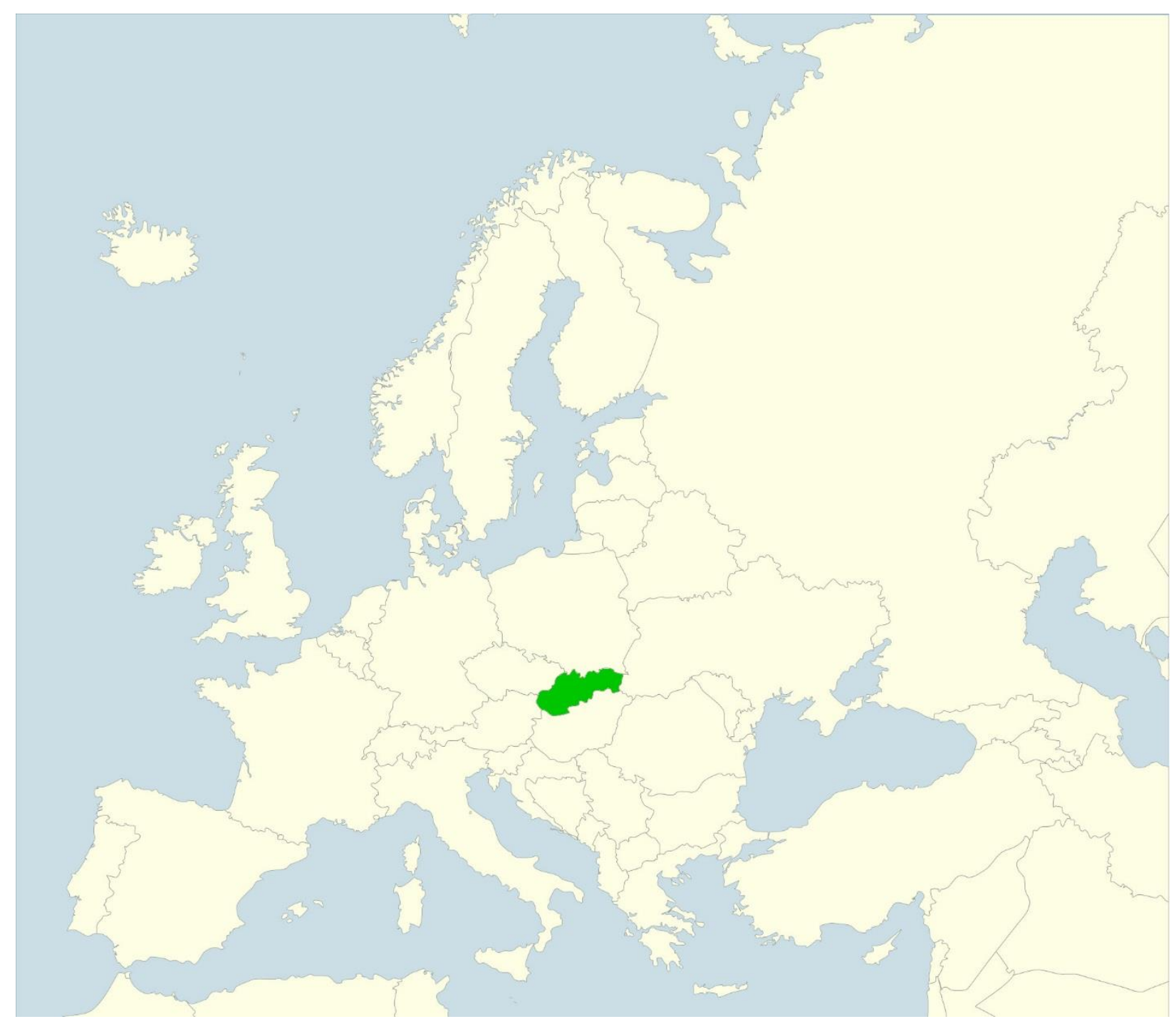

\footnotetext{
${ }^{1}$ Ing. Marcela Chreneková, PhD., Department of Regional and Rural Development, Faculty of European Studies and Regional Development, Slovak University of Agriculture, Trieda A. Hlinku 2, 94976 Nitra, Slovak Republic, e-mail: marcela.chrenekova@uniag.sk. ORCID 0000-0001-5709-8940
} 


\begin{abstract}
The exclusion of individuals from the labour market directly affects the economic situation of their households. The main objective of the social economy is to address this situation. With the development of the social economy, efforts to assess its effects are intensified. The ambition of the paper is to express the extent of social economy in terms of rurality of regions of the Slovak Republic, identify its actors, sectors, where its entities operate and to illustrate both direct and indirect effects of the social economy. Industrial production is the most attractive sector for Slovak social enterprises. A small proportion of social enterprises operate in information, communication services and education. The largest number of sheltered workshops and workplaces operates in wholesale and retail trade and services related to sales. Geographical distribution of the social economy entities in Slovak districts (LAU 1) showed dependence of social economy intensity on rurality. Impact of a social enterprise is strongest in the local territory. However, single social enterprise can bring wide regional, national and even supranational effects.
\end{abstract}

Key words: social economy, social enterprises, sheltered workshops, protected workplaces, economic effects, social effects, environmental effects, Slovak Republic

Abstrakt: Vylúčenie jednotlivcov z trhu práce priamo ovplyvňuje ekonomickú situáciu ich domácností. Hlavným ciel'om sociálnej ekonomiky je riešit' túto situáciu. S rozvojom sociálnej ekonomiky sa zintenzívňuje úsilie o posúdenie jeho účinkov. Ciel'om príspevku je vyjadrit' rozsah sociálnej ekonomiky z hladiska rurality regiónov Slovenskej republiky, identifikovat' jej aktérov, sektory, kde pôsobia jej subjekty a ilustrovat' priame i nepriame vplyvy sociálneho hospodárstva. Priemyselná výroba je najatraktívnejším odvetvím slovenských sociálnych podnikov. Malá čast' sociálnych podnikov pôsobí $v$ oblasti informačných, komunikačných služieb a vzdelávania. Najväčší počet chránených dielní a pracovísk pôsobí vo vel'koobchode a maloobchode a službách súvisiacich s predajom. Geografické rozloženie subjektov sociálnej ekonomiky v slovenských okresoch (LAU 1) ukázalo závislost' intenzity sociálnej ekonomiky od vidieckosti. Vplyv sociálneho podniku je najintenzívnejší v mieste jeho pôsobenia. Jediný sociálny podnik však môže priniest' široké regionálne, národné a dokonca aj nadnárodné efekty.

Kl'účové slová: sociálna ekonomika, sociálne podniky, chránené dielne, chránené pracoviská, ekonomické vplyvy, sociálne vplyvy, environmentálne vplyvy, Slovenská republika

\title{
1. Introduction
}

The social economy is a phenomenon to provide innovative responses to the current economic, social and environmental challenges by developing sustainable jobs, social inclusion, improvement of local social and other services, social cohesion, regional and rural development, environmental protection, etc.

There are 2 million social economy enterprises, representing 10\% of all businesses in the EU. Approximately one in four businesses founded in Europe would therefore be a social enterprise. This figure rises quickly in some countries to one in three. More than 11 million people (about $6 \%$ of the EU's employees) work for social economy enterprises in the EU member states (European Commission, 2017). Within the social economy, selected countries are developed in employment possibilities to disabled persons by means of sheltered workshops and workplaces.

The social enterprise sector is still little understood, but on the other hand, there is an urgent need to assess its activities and its effects, because they operate in an open market and conditions must be clearly defined and policy tools (national law, public procurement procedures) specified. Impact assessment in social economy is important for a number of reasons, such as performance 
and sustainability argumentation for its public or non-public support, for further management, marketing, and sustainability of the entity operating in the sector.

Also, the recent attempt promoted by the European Commission to map social enterprises at a European level has confirmed a general inability to grasp the complexity of social enterprises and to include within their definition a plurality of initiatives that are not social enterprises under the law, but have the same characteristics (European Commission, 2015). Evaluation of social, societal and environmental value added is widely discussed by researchers, businesses, and policy-makers.

The ambition of the paper is to express the extent of social economy in urban and rural regions of the Slovak Republic, identify its actors, sectors in which its entities operate, and to illustrate both direct and indirect effects of the social economy.

\section{Theoretical background}

\subsection{Social economy in the EU}

The social economy as a tool of modern welfare system is rooted in different traditions. In EU member states, the co-operative, associative and voluntary traditions preceded creation of the system after the Second World War (Bornstein and Davis, 2010; Defourny, 2001; Korimová, 2014). In some of these countries (for example, France or Spain), social enterprises emerged mainly from co-operative and mutual aid societies background, in others (Italy, UK), voluntary and civic engagement of citizens was the social economy development factor (European Commission, 2016). In new member countries, as in the Visegrad region countries, the public policy driver is considered to be the most important factor of social economy emergence.

The social entrepreneurship is a phenomenon that is present in all EU member states, regardless of the type of socio-political doctrine and welfare system. Social enterprises as, in most cases, bottom up initiatives contributed to modifying welfare systems, sometimes profoundly, by extending the range of actors and redesigning the services supplied (Kerlin, 2012; OECD, 2016) and widening direct and indirect effects.

European Commission (2011) define social enterprises as those businesses in which the social or societal objective of the common good is the reason for the commercial activity, often in form of a high level social innovation. Profits of these businesses are mainly reinvested with a view to achieving social objective, and the method of organisation or ownership system reflects the mission.

Social businesses perform a range of socially beneficial activities in different sectors. The most notable are the sphere of social services, local development and integration of disadvantaged people (Defourny, Nyssens, 2010).

\subsection{Legal forms and sectors}

Legal form of the social economy entity can be different (Korimova 2014; Tapio et al. 2014; European Commission, 2017), but there are specific forms in different countries. The specific legal statuses are particularly suited to social enterprises as their method of governance favours participation and openness. They can operate as cooperatives, mutual societies, non-profit associations, foundations as well as social enterprises in the form of an ordinary private or public limited company. Associations are prevalent in countries in which the associative model permits a certain degree of freedom in the performance of entrepreneurial activities, in particular as regards the sale of goods and services on the market, as in France and Belgium and some of the new EU member states, such as Slovenia and Bulgaria (OECD, 2016). Conversely, in countries where the economic activities of associations are limited, as in the case of Italy or the Nordic countries, social enterprises are more frequently created in the legal form of cooperatives (Lehtonen, Tykkyläinen, 2014; European Commission, 2015; Lundgaard-Andersen et al., 2017; Chreneková, Billik, 2017). Social economy entities are mostly micro, small, and medium-sized enterprises (OECD, 2016). They may operate in any sector or industry and a broad number of commercial activities, provide a wide range of products and services mostly of general interest to the community. They can operate in areas where the state and the market fail. Social 
economy entities can bring innovative solutions in areas of administrative or other inability. In the social economy business, all five innovative combinations, defined by Schumpeter (1949) introducing a new product or changing product quality, introducing new production processes, opening up new markets, acquiring new raw material resources, and reorganizing its sector, can be observed.

\subsection{The triple bottom line and impact of the social economy}

It is important to assess the value added of social economy entities and projects. Main reasons of the evaluation are two-fold: estimating performance of entities and projects for its further management, obtaining support from external sources to ensure sustainability of the entity or project. There are many evaluation approaches and methods in social economy. However, as most social businesses are unique and original, methods of assessment must be, to considerable extent, tailor-made and original (Reeder et al., 2012; Venclík et al., 2016). Some methods of evaluation are focused on examining and measuring individual aspects (for example, social capital, quality of internal processes, business performance, level of employment of disadvantaged people). Other evaluation approaches, seek to focus on a comprehensive assessment of the overall social or societal added value involving a wide range of stakeholders (Yunus, 2010; Venclík et al., 2016). However, the main precondition of the assessment is availability of data that show the entity or project performance. This can be a challenge as certain categories of social and environmental effects and benefits are not measurable or monetizable. Measuring sustainable performance has to be conceptually based but simplified to be practically useful (Hubbard, 2009).

Principles of the social economy and social entrepreneurship are based on the idea of triple bottom line - TBL (Elkington, 1994 and 1999), which is an accounting framework incorporating social, environmental and financial dimension of performance. The three triple bottom line dimensions can be thus used in the process of evaluation of social economy effects (Yongvanich, Guthrie, 2006; Slaper, Hall, 2011; Gillis, James, 2015). Qualitative and quantitative techniques are appropriate in determining a strategy for approaching and formulating a measurement framework for all three dimensions (Henriques, Richardson, 2004; Magee et al. 2013). Stakeholder engagement in TBL reporting is stressed (Gross, 2015). The spatial aspect of the social economy enables to estimate the effectivity and effects of the sector on social development of regions.

\section{Methodology}

Main objective of the paper is to express the extent of social economy in urban, intermediate, and rural regions of the Slovak Republic, identify its actors, sectors, where its entities operate and to illustrate both direct and indirect effects of the social economy.

Social economy is defined as a sum of productive, distribution or consumer activities carried out through economic or non-economic activity, independently of the state authorities, whose main objective is to achieve a positive social impact. A civic association, foundation, non-investment fund, non-profit organization, special purpose church, business company, cooperative or natural person - employer can be considered as an entity of the social economy (Slovak Act no. 112/2018 about the social economy and social enterprises).

It is methodologically difficult to specify all social economy subjects and determine and quantify their activities with social impact and to obtain data about them. Three types of social economy subjects were selected for the study. These are: sheltered workshops, protected workplaces and social enterprises. Main source of data for basic characteristics (location, workforce, sectors) of these entities was register of social economy entities managed by Central Office of Labour, Social Affairs and Family of the Slovak Republic. We have studied 5,379 sheltered workshops and sheltered workplaces and 94 social enterprises registered in the territory of the Slovak Republic until the end of February 2018. However, it is not possible to determine the number of active social enterprises after March 2018, as former register of social enterprises doesn't exist anymore and according to the new law on social economy (Act no. 112/2018), the situation in registration of social economy entities is consolidated. 
The regional distribution of sheltered workshops, protected workplaces and social enterprises in terms of rurality is expressed in the map output (processed using ArcView GIS 3.2).

As for rurality, we used typology of districts published by Fáziková and Stehlíková (2006). According to this, there are 33 rural, 37 intermediate and 9 urban districts in the Slovak Republic.

For identification of actors of the social economy, as sources of information, we also used interviews with 5 experts and 45 managers of social enterprises conducted from January to March 2017.

Eastern Slovakia is specific in its development challenges. This is caused by many factors. Development trajectories of settlements and concentration of Roma community is mentioned in several studies (e.g. Novotný et al., 2016). To illustrate direct, indirect, local and wider effects of a social enterprise, we processed a case study. For the case study, we selected a case of Eastern Slovakia settlement. We chose one of the first social enterprises established in the Slovak Republic - limited company Hrhovské služby, s.r.o. located in Spišský Hrhov (Prešov NUTS 3 Region). It operates as a municipal company formed as a work integration enterprise and a sheltered workshop at the same time. The case stands for typical Slovak municipal social enterprise dealing with development challenges caused by concentration of Roma community.

After the study of secondary sources, conducting a public pool (6\% of Spišský Hrhov citizens and 11 employees of the social enterprise in September 2016), interviews (with 2 managers) and participating observations (one week personal stay and 5 personal visits), we identified direct and indirect economic, social and environmental effects the social enterprise has on the local community and territory, as well as its wider impact.

\section{Actors of the Slovak social economy}

Actors of the social economy are those, who are directly or indirectly involved in its activities.

In general, the objects of the social economy are individuals and groups that are disadvantaged and marginalized for various reasons in a given socio-economic system oriented towards measures of the social economy (Korimová, 2007). These are: people with disabilities, young people and young adults in difficult life situation, people without shelter and after serving a sentence, people with addictions, ethnic minorities, the long-term unemployed, etc.

In the Slovak Republic, basic rules of the social economy were set by the Act No. 5/2004 on employment services until May 2018. From $1^{\text {st }}$ May 2018, Act no. 112/2018 about the social economy and social enterprises is in force. The subject of the social economy is, for the purposes of this Act, defined as a legal or a natural person who achieves measurable positive social impact as its initial social objective in accordance with its statutes, other rules or founding documents. According to the definition, this person provides goods or services to vulnerable, marginalized, disadvantaged or excluded persons, uses a method of production of goods or services that represents its primary social objective, uses at least $50 \%$ of the revenue generated by the activity (after the payment of all the expenses for the activity for the relevant taxable period under the tax return) to achieve its initial social objective. Social economy entity is managed responsibly and transparently, in particular by involving employees, customers and stakeholders concerned with its business activities.

The same Act also defines the social enterprise of labour integration as a basic subject of the social economy. It is "a legal or natural person whose at least $30 \%$ employees has been disadvantaged job seekers prior to recruitment. The person provides support and assistance to its employees and uses its revenue for the creation of new jobs or for the improvement of working conditions. Other types of social enterprises do not have the legislative capabilities to acquire "social enterprise status".

One of the most important forms of support for the employment of citizens with health disabilities is the possibility of setting up other social economy entities - sheltered workshops and workplaces (also regulated by the Act No. 5/2004). These provide jobs created by a legal or natural person and employing disabled citizens who are unable to work in the labour market or at the workplaces, where people with disabilities are prepared or trained for the work. 
Working conditions and demands for the work performance of disabled people are adapted to their state of health at these workplaces. A sheltered workplace can also be established by a disabled citizen in his own household. A production cooperative of invalids is also included in the category.

The main actors, influencing the activities of social enterprises are the public administration, the non-profit sector and the European Union. The state is a key player in the social economy. Its role is to create and secure space and a system of incentives for the functioning of the social cohesion mechanisms. The Slovak Ministry of Labour, Social Affairs and Family is the state governing body of most social economy activities. The Ministry of Health and the Ministry of Economy are involved partially. The position of the state in the social economy significantly influences other entities in the system. Central Office of Labour, Social Affairs and Family of the Slovak Republic and its regional offices act as a state body ensuring the performance of the state administration in social affairs and employment services. The Central Office, inter alia, creates and manages the Register of Social Enterprises of Work Integration and the Register of Sheltered Workshops and Workplaces.

Municipalities, regional authorities and conventional business entities either provide social services or create social economy workplaces. The primary assistance from the state, region and municipalities to social business should be based on a socially responsible behaviour, such as subscribing services and looking for suppliers of these services in order to enable functioning of social businesses.

\section{Spatial aspects of the social economy}

There are 5,379 sheltered workshops and sheltered workplaces in the territory of the Slovak Republic. Almost a fifth of them is located in Prešov Region. This Region is the strongest one as for number of sheltered jobs per 10,000 inhabitants as well. The lowest number of the entities is situated in Bratislava Region, which is the most developed region (it is the only Slovak region with more than $90 \%$ of GDP of EU average GDP per capita). Sheltered workshops and workplaces throughout the Slovak Republic create 9,831 jobs for disabled jobseekers. The regional distribution of sheltered workshops, workplaces and jobs created in these entities is illustrated in Table 1.

Tab 1. Regional distribution of sheltered workshops and workplaces (SWW). Source: Central Office of Labour, Social Affairs and Family of the Slovak Republic; Janek, 2017

\begin{tabular}{|l|r|r|r|r|}
\hline Region (NUTS 3) & Number of SWW & $\begin{array}{c}\text { Number of SWW } \\
\text { per 10,000 } \\
\text { inhabitants }\end{array}$ & $\begin{array}{c}\text { Number of jobs } \\
\text { in SWW }\end{array}$ & $\begin{array}{c}\text { Number of jobs in } \\
\text { SWW per 10,000 } \\
\text { inhabitants }\end{array}$ \\
\hline Bratislava & 274 & 36 & 550 & 73 \\
\hline Košice & 735 & 93 & 1,373 & 179 \\
\hline Prešov & 1,029 & 213 & 1,916 & 363 \\
\hline Žilina & 952 & 150 & 1,505 & 230 \\
\hline Banská Bystrica & 671 & 142 & 1,319 & 262 \\
\hline Nitra & 506 & 51 & 932 & 109 \\
\hline Trnava & 393 & 47 & 815 & 180 \\
\hline Trenčín & 819 & 103 & 1,421 & \\
\hline
\end{tabular}


Disabled citizens have the slightest chance to work in a sheltered workshop or a sheltered workplace in the Bratislava Region, because only 73 such jobs per 10,000 inhabitants are created there. Incorporating these people into the labour market has a significant positive impact on the quality of their lives.

As far as the legal form of founders of sheltered workshops and workplaces is concerned, legal entities (52\%) represent the most numerous group. Natural persons create $46 \%$ of them and the remaining two percent of founders are cities, municipalities and non-profit organizations.

Social enterprise is another form of social economy entities of our interest. Their creation was supported within the cohesion policy programming period 2007-2013. From 2008 to 2017, altogether 94 registered social enterprises were established in the Slovak Republic. We have analysed all of them. It is not possible to determine the number of active entities and jobs in the social enterprises properly, as there is currently no comprehensive register of active entities. New enterprises are emerging within the government programme aimed at support to the least developed districts, where enterprises operating in education, manufacturing, agriculture and tourism are likely to be supported.

Sheltered workshops and workplaces

Social enterprises
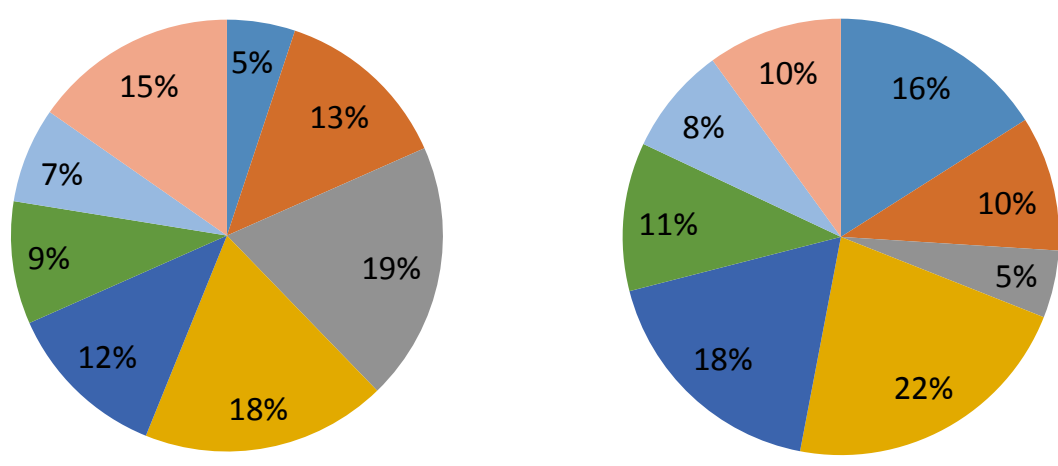

Bratislava
Košice
Prešov
Žilina
Banská Bystrica
Nitra
Trnava
Trenčín

Fig 1. Regional (NUTS 03) distribution of sheltered workshops and workplaces and social enterprises. Source: Central Office of Labour, Social Affairs and Family of the Slovak Republic

As for the legal form of the entities established, all of them were founded as legal persons, $81 \%$ of them as limited companies, $15 \%$ originated as non-profit organizations and $3 \%$ were associations. One third of them are municipal entities.

As it was stated before, it is important to study the spatial aspect of the social economy as it enables us to assess the effectivity and impact the sector has on the social development of regions. We expressed regional distribution of sheltered workshops and workplaces and regional distribution of social enterprises.

Žilina Region has a strong position in both categories of entities, Prešov Region is strong only in the sheltered workshops and workplaces and the position of Bratislava and Banská Bystrica Regions predominates in the category of social enterprises.

One of the main objectives of social enterprises is work integration. Target groups of enterprises are citizens excluded from the labour market and those long-term unemployed. The logical prerequisite for the establishment of social enterprises is a high unemployment rate. However, the distribution of social enterprises on the level of NUTS3 Slovak regions does not reflect the employment situation. This was also the reason why the state support to the least developed districts and their social economy was launched in 2015. 


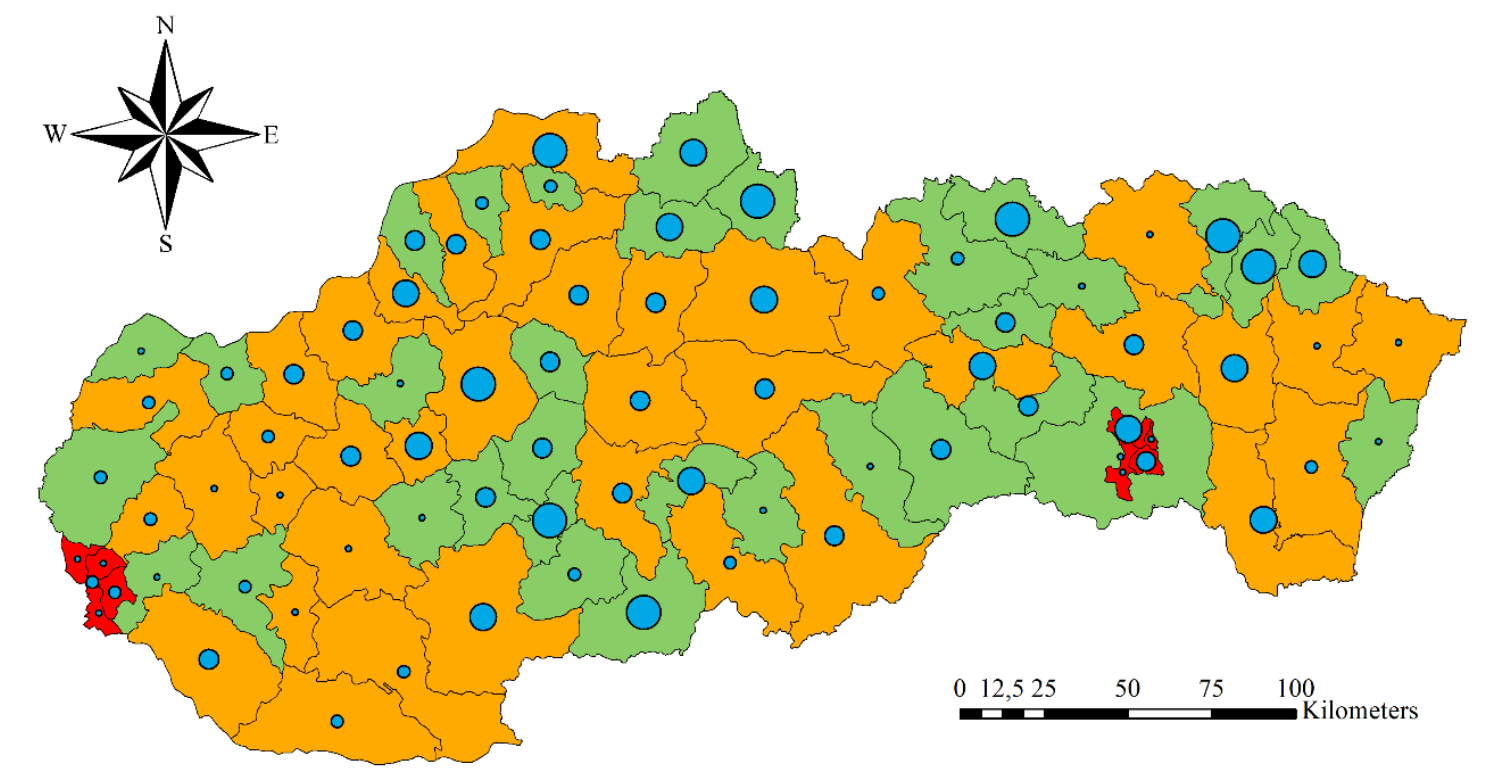

Number of social economy subjects per 10000 inhabitants

Rurality of districts

- $0,79-5,26$

- $5,27-8,21$

- $8,22-12,92$

$12,93-22,37$

$22,38-57,68$

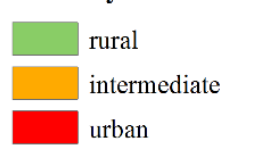

Fig 2. Regional (LAU1) distribution of sheltered workshops and workplaces and social enterprises in terms of rurality of regions. Source: own processing

We also considered geographical distribution of the studied types of social economy entities in Slovak districts by rurality. The map illustration (Figure 2) shows the number of sheltered workshops and workplaces and social enterprises per 10,000 inhabitants in terms of rurality. We considered three categories of Slovak districts - 33 rural, 37 intermediate and 9 urban districts. The three types of social economy entities are mostly concentrated in the mentioned districts, which are rural and at the same time marginal from the national point of view. While the average number of social economy entities in rural districts is 12.71 per 10,000 inhabitants, it is 10.08 entities in intermediate districts and only 6.72 in urban districts. It shows a clear dependence of social economy intensity on rurality. However, there are certain exceptions. In the case of Revúca rural district, it is only 2.99 entities per 10,000 inhabitants. Contrary to this, Košice I urban district has 20.37 entities per 10,000 inhabitants.

The highest number of sheltered workshops and workplaces is located in the districts of Prešov, Bardejov, Svidník, Medzilaborce and Stropkov. The districts of Žilina (NUTS 3) Region - Tvrdošín, Čadca, Dolný Kubín - and Trenčín (NUTS 3) Region - Prievidza, Ilava and Trenčín - have higher number of entities that established protected workshops and workplaces as well. The lowest numbers were recorded in the districts of Bratislava, Senec, Lučenec, Poltár, Snina and Humenné.

Most of the social enterprises are located in Banská Štiavnica rural district and Čadca intermediate district. There is no social enterprise in one half of districts in each group (rural, intermediate and urban). 


\section{Economic activities of social economy entities}

Social entrepreneurship and, in particular, enterprises oriented to the work integration may, in principle, be involved in any economic activity. In its strategic documents, the European Commission also lists economic activities that cover a wide range of activities from production to services in various fields, including tourism.

Tab 2. Economic activities of social economy entities. Source: Central Office of Labour, Social Affairs and Family of the Slovak Republic

\begin{tabular}{|c|c|c|}
\hline $\begin{array}{l}\text { Section within the economic activity classification } \\
\text { (SK NACE) }\end{array}$ & $\begin{array}{c}\text { Proportion } \\
\text { of sheltered } \\
\text { workshops } \\
\text { and } \\
\text { workplaces } \\
(\%) \\
\end{array}$ & $\begin{array}{c}\text { Proportion } \\
\text { of social } \\
\text { enterprises } \\
(\%)\end{array}$ \\
\hline $\begin{array}{l}\text { Wholesale and retail trade, repair of motor vehicles and } \\
\text { motorcycles }\end{array}$ & 26 & 6 \\
\hline Industrial production & 17 & 31 \\
\hline Other activities & 10.5 & 1 \\
\hline Administrative and support services & 10 & 13 \\
\hline Professional, scientific and technical activities & 9 & 0 \\
\hline Public administration and defense, compulsory social security & 6 & 0 \\
\hline Health and social assistance & 5 & 0 \\
\hline Accommodation and catering services & 4 & 14 \\
\hline Education & 3 & 1 \\
\hline Construction & 2 & 15 \\
\hline Information and communication & 2 & 3 \\
\hline Art, entertainment and recreation & 2 & 0 \\
\hline Electricity, gas, steam and cold air supply & 1 & 12 \\
\hline Financial and insurance activities & 1 & 0 \\
\hline Real estate activities & 1 & 0 \\
\hline Transport and storage & 0.5 & 2 \\
\hline Water supply, wastewater and waste treatment & 0 & 15 \\
\hline Activities of extraterritorial organizations and associations & 0 & 1 \\
\hline
\end{tabular}

Although there is a high share of enterprises conducting business in construction, accommodation, catering, and administrative and support services, industrial production is the most attractive sector for Slovak social enterprises. Surprisingly, a small proportion of social enterprises operate in information, communication services and education.

Sheltered workplaces should focus primarily on the sectors where jobs can be adapted for disadvantaged job-seekers. The largest number of sheltered workshops and workplaces operates in wholesale and retail trade and services related to sales, including motor vehicle repairs. They most often employ their employees as salespersons or retailers. The second major group of economic activities is the industrial production, mostly textile sector (preparation and spinning of textile fibres, weaving and finishing of textiles of clothing). It is followed by the section of personal services (hairdressing, cosmetics and other services).

\section{Local effects of social entrepreneurship - case of Spišský Hrhov municipality}

Societal responsibility is the main principle of the social economy. Primary effects of social entrepreneurship are thus linked to local community and environment. However, it can influence a wider area as well. The effects can be specific and they depend on the type of activities, goods and services provided. 
Tab 3. Local level triple bottom line impact of social enterprise in Spišský Hrhov". Source: own processing; Lenčéšová, 2017

\begin{tabular}{|c|c|c|}
\hline Effects & Direct & Indirect \\
\hline Economic & $\begin{array}{l}\text { increase in employment } \\
\text { creation of jobs } \\
\text { completion of technical } \\
\text { infrastructure } \\
\text { reduction of the cost of running } \\
\text { and managing water supply and } \\
\text { sewerage } \\
\text { improvement of municipal } \\
\text { amenities } \\
\text { increase in the skills and acquiring } \\
\text { of new skills } \\
\text { increase in the market value of } \\
\text { land and public buildings } \\
\text { acquisition and efficient use of } \\
\text { external resources (national and } \\
\text { European support schemes) } \\
\text { synergy in using funds and } \\
\text { resources }\end{array}$ & $\begin{array}{l}\text { creation of conditions for the } \\
\text { development of tourism } \\
\text { creation of conditions for building } \\
\text { the economic base of the } \\
\text { municipality } \\
\text { creation of business opportunities } \\
\text { support for spin-off processes }\end{array}$ \\
\hline Social & $\begin{array}{l}\text { improvement of the social status } \\
\text { of households } \\
\text { social inclusion of individuals and } \\
\text { groups threatened by exclusion } \\
\text { improvement of the quality of } \\
\text { human capital } \\
\text { construction of lower-cost rental } \\
\text { flats } \\
\text { an increase in the number of } \\
\text { sports and cultural activities } \\
\text { improving the supply and quality } \\
\text { of social services }\end{array}$ & $\begin{array}{l}\text { increase in the school attendance } \\
\text { of Roma children } \\
\text { reduction of social tensions and } \\
\text { improving personal relations } \\
\text { between citizens } \\
\text { increase in the quality of social } \\
\text { capital } \\
\text { increase in the participation of } \\
\text { citizens in public activities } \\
\text { community social work }\end{array}$ \\
\hline Environmental & $\begin{array}{l}\text { construction of the waste water } \\
\text { treatment plant and completion of } \\
\text { sewerage system } \\
\text { completion of public water supply } \\
\text { forest cleaning } \\
\text { recovery of waste wood } \\
\text { planting and maintenance of } \\
\text { public greenery and landscaping } \\
\text { cleaning of public spaces } \\
\text { revitalization of the historic park } \\
\text { waste separation } \\
\text { collection of secondary raw } \\
\text { materials }\end{array}$ & $\begin{array}{l}\text { efficient use of natural resources } \\
\text { increase in environmental } \\
\text { awareness of the population } \\
\text { education of children and youth } \\
\text { in the field of environmental } \\
\text { protection }\end{array}$ \\
\hline
\end{tabular}


We chose one of the first social enterprises established in the Slovak Republic as an example of various impacts - limited company Hrhovské služby, s.r.o. located in Spišský Hrhov (Prešov NUTS 3 Region). It operates as a municipal company formed as a work integration enterprise and a sheltered workshop simultaneously. Roma community is the target group of the work integration.

The company is aimed at construction, maintenance and adjustment of public spaces and roads, production of semi-finished and finished products, greenery and gardening, organization of events, and maintenance of sport facilities.

After the public pool, interviews and participating observations, we identified direct and indirect economic, social and environmental effects the social enterprise has on the local community and territory, as well as its wider impact.

\section{Wider impact of social entrepreneurship in Spišský Hrhov}

In addition to the impact on the local territory and the community, we have also identified impacts on the wider territory. These are regional, national and supranational.

\section{Regional impact}

Work integration and social inclusion of Roma community is, mainly in Eastern Slovakia, a long term challenge. Example of Spišský Hrhov is a solution example and motivation for the surrounding cities and villages. Representatives of the other municipalities asked for advice. This is why a training centre focused on practical issues of social business was established directly in the village of Spišský Hrhov. Practitioners and decision-makers come for excursions.

National and supranational impact

Slovak university students and teachers come to the municipality to acquire practical knowledge about cooperation of actors, strategy formulation and its implementation, functioning of selfgovernment, social business, facilitation of development processes etc.

Actors of the Spišský Hrhov social economy also act in extension and education, conducting lectures at Slovak universities and publishing teaching materials. For example, the mayor of the municipality Vladimír Ledecký and community development facilitator Michal Smetanka are members of national policy expert groups as for example The expert group for development of least developed districts (managed by the Slovak Government Office), but also other groups aimed at national and regional strategy documents and acts concerning social economy and related issues.

In 2015, Spišský Hrhov was awarded in the European Prize of Village Restoration, where it took interest in preserving rural communities, partnerships, tangible and intangible heritage, community care, and realizing unique activities leading to harmonious development village. It was also awarded an extraordinary prize for the coexistence of all population groups in the village.

The village is visited by experts from neighbouring countries. Individual actors are members of international organizations and are also involved in international projects. In September 2017, an article on a successful Roma issue in Spišský Hrhov was published in the New York Times and other journals.

\section{Conclusion and discussion}

The social economy is still little understood because of plurality and specificity of its initiatives throughout countries and regions. Despite this fact, there is a need to assess its activities and impact.

Main aim of the paper is to express the extent of social economy in regions of the Slovak Republic, identify its actors, sectors, where its entities operate and to illustrate both direct and indirect effects of the social economy. 
We expressed regional distribution of sheltered workshops and workplaces and regional distribution of social enterprises on the level of NUTS 3 and LAU 1 regions. Distribution of social enterprises on the level of NUTS3 Slovak regions does not reflect the employment situation.

We also considered geographical distribution of the social economy entities in Slovak districts (LAU 1) by rurality. There is clear dependence of social economy intensity on rurality. However, social enterprises are absent in half of districts in each group (rural, intermediate and urban).

There is a high share of social enterprises conducting business in construction, accommodation, catering, and administrative and support services. Industrial production is the most attractive sector for Slovak social enterprises. Surprisingly, a small proportion of social enterprises operate in information, communication services and education. The largest number of sheltered workshops and workplaces operates in wholesale and retail trade and services related to sales, including motor vehicle repairs. They most often employ their employees as salespersons or retailers.

Potential effects of social economy in Slovak conditions, were expressed by Lubelcová (2012). According to her, the main impact can be reflected in: locally specific employment, development of services in tourism and personal social services, social inclusion, development of local social potential. This was confirmed also in the case study of Spišský Hrhov. Impact of a social enterprise is strongest in the local territory. However, single social enterprise can bring wide regional, national and even supranational effects. The assumption of success is open management and experienced managers.

\section{Acknowledgements}

Special thanks are extended to Vladimír Ledecký, Michal Smetanka and Peter Strážik (development actors from Spišský Hrhov), Lucia Lenčéšová and Martin Janek (SUA students), for their participation in the research, and Lukáš Varecha (SUA student) for processing statistical data.

Academic references

[1] Bornstein, D. \& Davis, S. (2010). Social Entrepreneurship. What Everyone Needs To Know. Oxford University Press.

[2] Defourny, J. (2001). From Third Sector to Social Enterprise. In Borzaga, C., Defourny, J., eds., The Emergence of Social Enterprise (pp. 1-18). London: Routledge.

[3] Defourney, J., Nyssens, M. (2010). Conception of Social Enterprise and Social Entrepreneurship in Europe and the United States: Convergence and Divergences. Journal of Social Entrepreneurship, 1(1), 32-53. DOI: 10.1080/19420670903442053.

[4] Elkington, J. (1994). Towards the Sustainable Corporation: Win-Win-Win Business Strategies for Sustainable Development. California Management Review 36(2), 90-100. DOI: $10.2307 / 41165746$.

[5] Elkington, J. (1999). Cannibals with Forks: The Triple Bottom Line of $21^{\text {st }}$ Century Business. Capstone: John Wiley.

[6] Fáziková, M. \& Stehlíková, B. (2006). Nové prístupy ku klasifikácii vidieckych regiónov. Ekonomika pol'nohospodárstva, 6(2), 23-31.

[7] Gillis, W. \& James, M. S. L. (2015). The Impact of the Triple Bottom Line on Social Entrepreneurship. In The Fifth International Conference on Engaged Management Scholarship (not paged). DOI: 10.2139/ssrn.2676325.

[8] Gross, R. (2015). Measuring Organizational Performance: A New Approach To Triple Bottom Line Reporting And Stakeholder Engagement. British Journal of Business and Management Research. 2(1), 69-80. 
[9] Henriques, A., Richardson, J., eds. (2004). The Triple Bottom Line: Does it All Add Up? Abingdon-on-Thames: Taylor \& Francis.

[10] Hubbard, G. (2009). Measuring organizational performance: beyond the triple bottom line. Business Strategy and the Environment. 18(3), 177-191. DOI: 10.1002/bse.564.

[11] Janek, M. (2017). The Social Economy in Slovakia [bachelor thesis]. Nitra: Slovak University of Agriculture.

[12] Kerlin, J. A. (2012). Defining Social Enterprise Across Different Contexts: Conceptual Framework Based on Institutional Factors. Non-profit and Voluntary Sector Quarterly, 42(1), 84-108. DOI: 10.1177/0899764011433040.

[13] Korimová, G. (2007). Predpoklady rozvoja sociálnej ekonomiky. Banská Bystrica: Univerzita Mateja Bela.

[14] Korimová, G. (2014). Sociálna ekonomika a podnikanie. Banská Bystrica: Belianum.

[15] Lehtonen, O. \& Tykkyläinen, M. (2014). Potential Job Creation and Resource Dependance in Rural Finland. European Countryside 6(3), 202-224. DOI: 10.2478/euco-2014-0011.

[16] Lenčéšová, L. (2017). Social entrepreneurship and its effects - case study of Spišský Hrhov [diploma thesis]. Nitra: Slovak University of Agriculture.

[17] Lubelcová, G. (2012). Sociálna ekonomika: koncepty, príležitosti, riziká. Sociológia. 44(1), 62-82.

[18] Lundgaard-Andersen, L., Gawell, M. \& Spear, R., eds. (2017). Social Entrepreneurship and Social Enterprises - Nordic Perspectives. London: Routledge.

[19] Magee, L., Scerri, A., James, P., Thom, J. A., Padgham, L., Hickmott, S. \& Cahill, F. (2013). Reframing social sustainability reporting: towards an engaged approach. Environment, development and sustainability, 15(1), 225-243. DOI: 10.1007/s10668-012-9384-2.

[20] Novotný, L., Csachová, S., Kulla, M., Nestorová-Dická, J. \& Pregi, L. (2016). Development Trajectories of Small Towns in East Slovakia. European Countryside. 8(4), 373-394. DOI: 10.1515/euco-2016-0026.

[21] Reeder, N., O' Sullivan, C., Tucker, S., Ramsden, P. \& Mulgan, G. (2012). Strengthening social innovation in Europe: journey to effective assessment and metrics. Brussels: European Commission. DOI: 10.2769/53098.

[22] Schumpeter, J. A. (1949). Economic theory and entrepreneurial history. In Wohl, R. R., ed., Change and the entrepreneur: postulates and the patterns for entrepreneurial history. Cambridge, MA: Harvard University Press.

[23] Slaper, T. F. \& Hall, T. J. (2011). The Triple Bottom Line: What Is It and How Does It Work? Indiana Business Review 86(1), 4-8.

[24] Tapio, R., Havukainen, I. \& Kuittinen, V. (2014). Common Power - Social Enterprise and Renewable Energy. Joensuu: Karelia University of Applied Sciences.

[25] Yongvanich, K. \& Guthrie, J. (2006). An extended performance reporting framework for social and environmental accounting. Business Strategy and the Environment 15(5), 309-321. DOI: $10.1002 /$ bse.541.

[26] Yunus, M. (2010). Building Social Business: The New Kind of Capitalism that Serves Humanity's Most Pressing Needs. New York: Public Affairs. 
[27] Act No. 5/2004 of the Slovak Republic on Employment Services and on amendments to certain acts of 4 December 2003. Available at: https://www.slov-lex.sk/pravnepredpisy/SK/ZZ/2004/5/20170501.

[28] Act No. 112/2018 of the Slovak Republic on Social Economy and Social Enterprises and on amendments to certain acts of 13 March 2018. Available at: https://www.slov-lex.sk/pravnepredpisy/SK/ZZ/2018/112/20180501.html.

[29] Chreneková, M. \& Billik, T. (2017). Social economy in the renewable energy sector. International Scientific Conference. Fast-growing Trees and Plants Growing for Energy Purposes. September 7-8th 2017 [poster]. Slovak University of Agriculture in Nitra.

[30] European Commission (2011). Communication from the Commission to the European Parliament, the Council, the European Economic and Social Committee and the Committee of the Regions Social Business Initiative creating a favourable climate for social enterprises, key stakeholders in the social economy and innovation. SEC (2011) 1278 final. Available at: http://eur-lex.europa.eu/legal-content/EN/TXT/PDF/?uri=CELEX:52011DC0682\&from=EN.

[31] European Commission. (2015). A Map of Social Enterprises and Their Eco-systems in Europe - country reports. Online. Available at:

http://ec.europa.eu/social/keyDocuments.jsp?advSearchKey=socentcntryrepts\&mode=adv ancedSubmit\&langld=en\&policyArea=\&type=0\&country=0\&year=0\&orderBy=docOrder.

[32] Venclík, M. et al. (2016). Sociální podnikání v praxi. Brno: Komora sociálních podniků.

[33] European Commission (2016). Social enterprises and the social economy going forward. A call for action from the Commission Expert Group on Social Entrepreneurship (GECES) European Union. Online. Available at: http://ec.europa.eu/growth/tools-databases/newsroom/cf/itemdetail.cfm?item_id=9024.

[34] European Commission (2017). Social enterprises and the social economy going forward. Expert Group on Social Entrepreneurship (GECES). Available at: http://ec.europa.eu/growth/sectors/social-economy/enterprises/expert-groups_en.

[35] OECD (2016). Boosting social entrepreneurship and social enterprise creation http://www.oecd.org/cfe/leed/Czech\%20Republic\%20Report\%20\%2006.03.17-FINAL.pdf. 